11

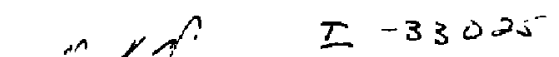

\section{STATUS OF THE SILICUN STRIP VERTEX DETECTOR FOR THE MARK II EXPERIMENT AT THE SLC*}

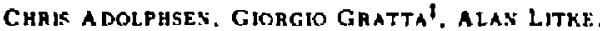
ANDAEAS SCHWARZ aND MICHAI. TLAALA"

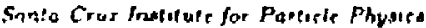

l'nuleraty of Coliforma, Santo Cruz, CA B500,

alar BREAKSTONE AND SHERWOOD PARKER

C'nuersily of Howas, Honolulu, $H$ 968RP

BRICE BARNETT, PAIL DALNCEY AXD, W DREWEK

Johns Hoghnd Uniteraify. Baltumore. MII PIela

end

ROBERT JACOBSEN AND VERA LUTh

Stanford Linear Accelerator Center Stanford Uneteraty, Stanford, Caljorna, 04,905
SLAC-PUB- 4452

DEB 8004626

\section{Abitract}

We are constructing a silicor strip vertex detertor to he wsce in the Ma:k Il detertar in the study of $Z^{c}$ decays at the SLAC Linear Colluder The atstus of the propect. including the performanre of the indiridual silicon delector modules, is presented

\section{Introduetion}

The Mark II detector will be the firat to tun at the SLAC Linear Collider (5LC) which is presently undergoing commissioning. Wie are building a ailieon alsip vertex detector (SSVD) lor this experiment to enhance the atudy of ohort lived particles produced in $Z^{0}$ decays. The SLC provides en excellent setting for the use of SSVD in a number of ways. The omall beam upot $\left[\sigma_{x, y}=2 \mu \mathrm{m} ; \sigma_{s}=1 \mathrm{~mm}\right)$ eaentially eliminated the interar lion point uncertainty while the tmal] beam pipe radius $(2.6 \mathrm{~cm})$ allows for a compact detectot and reduces the multiple ocattering contribution to the impact parmeter resolution. Also, the low beam crossing frequency $(120 \mathrm{H} x)$ permits a high density of channels since power to the aralog read-out electronice can be awitched off between pulses.

Given the apace conatrain Lo wikhin the Muk II delector, we settled for a SSVD design with three detector layeis that cover $77^{\circ}$ of the solid angle from the interaction point (see Ggure 1). The detectors measure position only in the $r-\phi$ plane; the Mark 11 central tracking chamber provide the $*$ information. The three layers insure that every track has at least two hils

- Woik supported by the Department of Energy, Contracts DE-ACOJ-76SF-00515, DE-AA03-76SFO0034, ind DE-AC03-83ER-40103 and the National Science Foundetion Grant 87 o1 6:0

* Fellow of Ltituto Niazionale di Fisica, Rome, Italy.

$\uparrow$ Visior from the Institule of Nuclear Physics, Krakow, Poland.
In the SSVD which unefulfor track finding esperially if back. grount rates are hif There are 12 delercors pes linger and 512 strips per detertor 8 ig a totai of about 18,000 channeis. The read-out of such a hig. density of atrips hes become possible in thir ias: fen yesn with the production of a custom VLS! chip $\left(-\right.$ H:croplex") of 128 rhannels that is roughly $6 \times 6 \mathrm{~mm}^{2} \mid 1$. The fabrication technology is NMOS using $5 \mu \mathrm{m}$ design rules. The cireuit integrates and stores (double correlaled sampling) the charge deposited on a strip and can multiplex the analog signal onto a serial bus. Another development which simplified the implementation of this project is the fabrication of detectors on four inch diameter silicon wafers [2]. This allows us to span a solid angle comparable to the central tracking chamber using only one detector length. The properties of the detectors are given in table 1 .

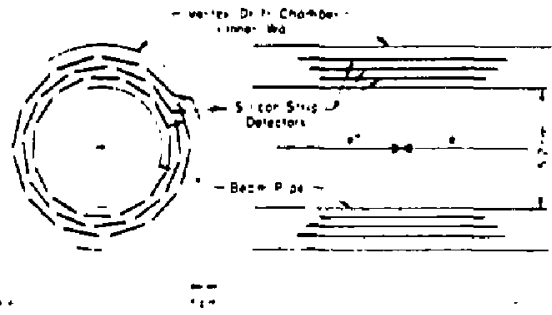

Figure 1. The layout of the Silicon Strip Verkx Detector.

\section{Beam Teats}

To determine the oignal characteristica of detectors with Micsoplex readout, we first built three fixed Larget atyle modules that were run in a $15 \mathrm{GeV}$ ponitron beam $|3|$. The deteclor otrips were $60 \mathrm{~mm}$ long, had $25 \mu \mathrm{m}$ pitch and were wire bonded 
Table 1

Properties of the Silicon betecers

\begin{tabular}{|c|c|c|c|c|}
\hline Detector Eroperty & Inyer 1 & layor $?$ & lnger 3 & units \\
\hline layer radius & 30 & 31 & $3 \pi$ & motn \\
\hline strip pileh & 25 & 20 & 33 & חואן \\
\hline mumber of strips & 512 & 512 & 512 & \\
\hline attire length & 72 & 82 & 90) & mfu \\
\hline tolal length & 75 & A; & 9 & men \\
\hline ac live width & 13 & 15 & 17 & niln \\
\hline tetal width & 14 & 16 & 18 & $\mathbf{m m}$ \\
\hline thirhuess & 300 & $3(x)$ & 300 & faim \\
\hline strip width & B & $y$ & 4 & atI! \\
\hline drpletion voltage: & -50 & $\sim 511$ & $\sim 50$ & $w$ \\
\hline $\begin{array}{l}\text { capacitance" } \\
\text { (to othet strips) }\end{array}$ & a.2 & 8.8 & 9.3 & plF \\
\hline $\begin{array}{l}\text { empne it.nnce' } \\
\text { (in benckplane) }\end{array}$ & 0.6 & 0.8 & 1.0 & $\mathbf{p F}$ \\
\hline ralculntod. & & & $\cdots$ & $--\cdots$ \\
\hline
\end{tabular}

to versun 2 of the Microples: chip for the benum at normal incinimure to the detector, the must probable entergy loss signal was 17 tines the average strip roise for the detector with the narrowes strip width $(111 \mathrm{\mu m})$. In thin case, the cuts used to And hits yielded essentially $100 \%$ efficiency for the hears signal while noise even ts occurred less than $10{ }^{5}$ per strip per trigger. 'The position resolution was bettor than is $\mu \mathrm{m}$ in each ease and two tracks could be resolved using a simple liading algneithm to within a separation of $150 \mathrm{~mm}$ witheut loss of alficiency or spatial resolution.

\section{Vertex Resolution}

Although a $5 \mu \mathrm{m}$ SSVD resolution provides a high aeci1racy point near the beam axis, the track angle is still better Hetermined from the large radial separation of measurements in the central drift chamber of the Mark IL. Considering the intrinsic resolutions of the tracking detectors in the Mark il including the SSVD, and the multiple scattering contribulion from materials of the detectors and beam pipe, the impact parameter resolution can be derived. The rosult is shown as a

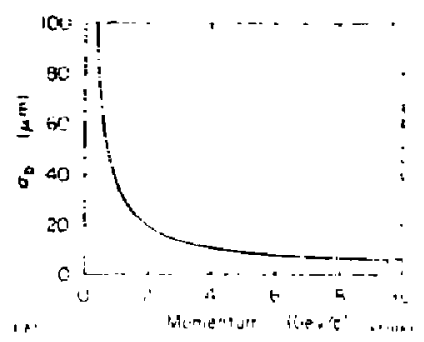

Figure 2. Impact parameter resolution $\left(\sigma_{b}\right)$ as a function of momentum for tracks produted at $90^{\circ}$ to the beam axis.

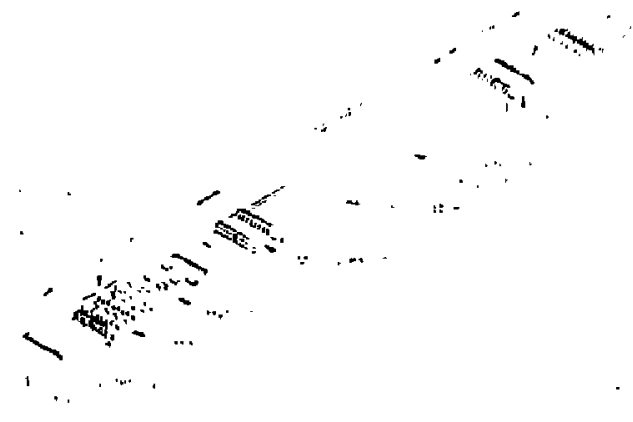

Figure 3. The plan for as silicun deturetop module.

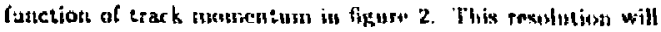
Rive good tikghing elficiency lor $b$ meson decisys, for: aximple. where the average secondary track momrntum is is few (jell/c nod the nean impact parameter is alomil $200 \mathrm{~mm}$.

\section{DeLectur Modulu,}

Sitice the bean tests, we have congtructed a number of protetype detector assembies that will lw. colupatible with the space iequirementa of the Mark II As shown in tigure 3 , the modulas consist of a detector with two puad-ou: chips wire bolded on euch end that process every (xther chanuel. "The Mi. croplex rhips are epaxied onto a liybrit eiecuil which peovides the control lines, a switchalule capneilor bisnk for the power, and a differential anplifier and line driver for the analog output signals. Flexible cables are used to bring the signals from the outside to wither ends of the modcle and from the hybrid to the read-out ehip. The outside cables are brought in along the beam pipe from only one end of the Marh il detector to ayoid ground loop problems and make the SSVD inctallation easier. The output analog signals are sent to an intelligent digitiecr, the BADC $|\boldsymbol{4}|$, which we are programmine to do on-line pedertal oubtraction and updatiag, cominen mode correction, and hil finding.

The Mleroplex chips we are currently using are version 3 which have been fabticated to cure problems with version 2 as well as to improve its performance. The new thips have lawer noise and consume less power (14 mW/channel analog and $.63 \mathrm{~mW}$, channel digital). The amplifier rise time is about 25 nsec and we generally use a 500 nsec integration period. The equivalent noise charge (ENC) of Microplex 3 as a function of the external inpul capacitance is shown in figure 4. This data were taken with a chip in which surface mount capacitors were wire bonded to the input pads. The data points have a normalization uncertainty of about $10 \%$. It should be noted that the strip noise spectrum adheres very well to a Ganssian distribution out to the limits of the data at five sigma.

One potential problein with using Microplex 3 is that the signal to noise ratio drops by a factor of two after about 20 krad of radiation exposure independent of whether the chip is powered or not [5]. Sitce it is still not cleter what the background radiation environment of the SSVD will be at the SLC, 


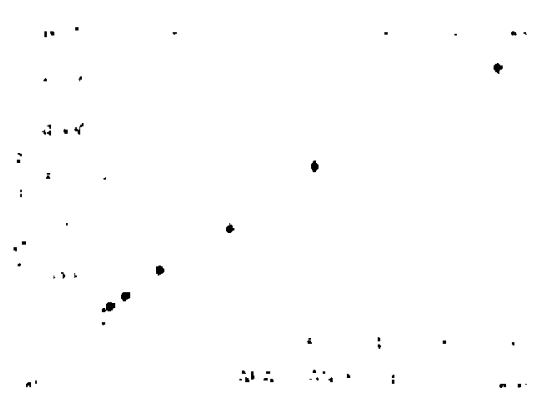

Figure 4. The equivalent charge noige (FNC) of Microplex 3 as a function of external input capncilance. Thr line fit to

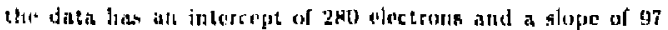
electrons $/ p F$.

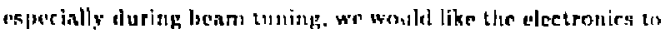
be as fac iation hard is possible. Consmuently, wr are plannirg another fabrication of the Microplex chip with rhanges geared toward anptoving its survival uuder rodiation exposture.

The silican strip detectors we wi]t une are wurh mote radiation re iisinl and show $a \approx 90 n A$ increase in leakage current per Mrad expoaure (> $4000 \mathrm{nd}$ salurates the amplifier). Limits on the initial leakage rurrents have been guaranteed by the manufacturer as has the maximam voltage for full depietion $(75 \mathrm{~V})$. At $10 \mathrm{~V}$ above the measured deplotion value, the leak. age cufretits should be sitaller than 20 nd for more than 970 of the stripg and nol more than $20 \mu \mathrm{A}$ in total. Also, no more than two stripe canl have curcents above $200 \mathrm{nA}$. 'These specifications ahould be readily achierable given that lon of the last twelve detector prolatypes we tested each have less than two strips with leakage currents above $20 \mathrm{nA}$ and all pass the depletion voltage requirement. Figure $S$ showg an example of a depletion measurement for one of the $30 \mathrm{mmn}$ long deteclors.

Limits on delector thickness (280 $1320 \mu \mathrm{m}$ ) have also been inet with the prototypes alchough only half pass a reyuirement that they are fat to $15 \mathrm{~mm}$. The concers here is that an

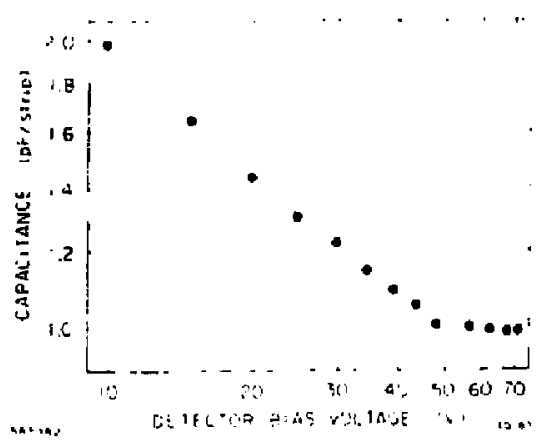

Figure 5. The strip to backplane capacitance as a function of the bias voltage for a $90 \mathrm{~mm}$ long detector. The leveling off of the data at about $30 \mathrm{~V}$ corresponds to full depletion of the detector. aplenarity translates inlo a $\phi$ error for tracks passing through the delec Lor at angles other than normat incidence (the :Tuximuta slope of trachs originating from the interaction point is ahout .2). Ilowever, the largest deviation from plartarity lor each detector is leas than $24 \mu \mathrm{m}$ and the bowing shape that is observed allows for a simplo geometrical correction to be anplied when determining losation of the hits.

\section{Module Performance}

To estimale the ajgal-to-noige ratio we can expect for minimun jonizing particles with our modules, we are measuring signals Irom $60 \mathrm{keV} X$-rayg produced from a $250 \mathrm{mCi}{ }^{24]} \mathrm{Am}$ source. These signals rorrespont to 71 \% of the most probable cnergy loss of minimum ionizing particles in $300 \mathrm{\mu m}$ silicon. The phourelectrons produced from the $X$-ray aboorplion have

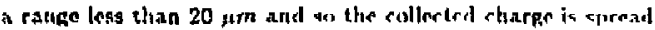

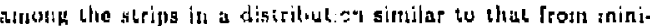
mum ionizing radiation.

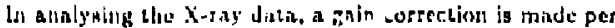
- trif that is equal ta the soverse of the rma naise of tial strip l'his is toutivated foor our measurenents bhowing that atthough the rms noise and average X-ray siganl may sary at the 20 ovel from strip-to-strip, their ratio is ronstant within errors. To lisst order. such uniformity is expected for elharge

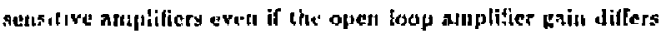
Iroun channel-to-clannel.

To lind $\mathrm{X}$-ray hits in a he data, we searelu for strips having a pulse height greater than five sigma noove the pedestal. $A$ clustre is defined as that strip plus the neighboring two strips on pither side. The distribution of tolal pulse !eight of the five steips, in units of the single channel rms nuise, is shonsts is ligure ofor data taken with one of the $72 \mathrm{~mm}$ long detec. tors. Figure 7 shows the aver age pulse liesght of the strip with the largest signal in the cluster as well as the average pulse heights of its neighboring strips The Gaussian fit to the data in figure 6 doos not include pointe from the low energy tail of the distribution. This tail resulus frorn lower energy $\mathbf{X}$-rays and events which occur near the edges of the aruplifier incegration period. The mean of the fitted curve is 13.3 sigma which extrapolates for minimum ionizing particles to a most probate energy loss that is 18.7 times the ringle channel noise. Assumi.ıg an electron-ion pair produced in silicon requires an avorage of $3.6 \mathrm{eV}$ energy deposiled, an equivalent noise charge of 1250 electrons is obtained which agrees within $10 \%$ of the expectation from figure 4 for a detector of $8.8 \mathrm{pF}$ total glrip capacitance (sum of strip-to-strip and strip-to-backplane capacitance). The standard devjation of the Gaussian curve in

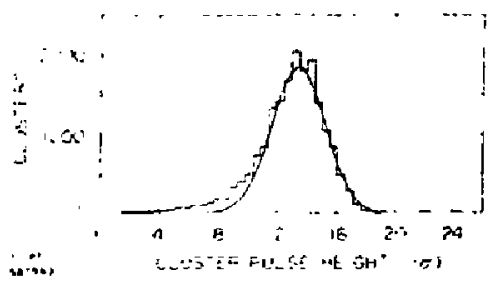

Figtre 6. The distribution of the cluster pulse height in unitu of the single channel stas roise ( $\sigma)$. 


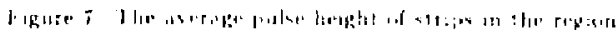

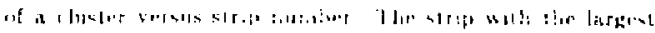
;

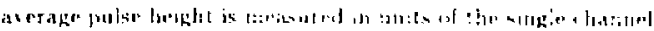
ruts i:oisan $|n|$

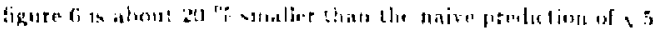

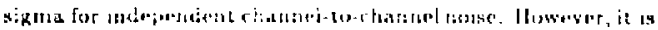

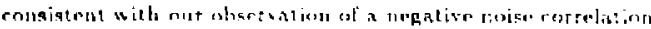

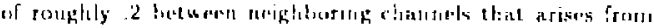
the raparative conpiath of the strips.

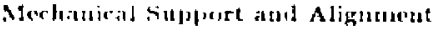

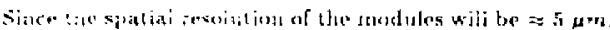
we heed to know their ioraliosta to a inuch better prerision.

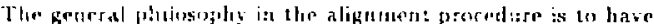

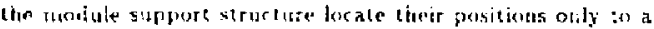

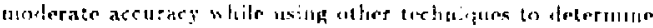

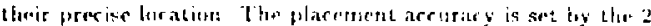

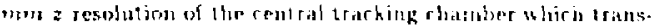

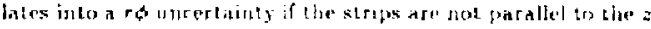

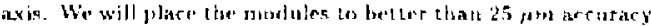

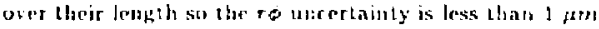

Whe photo in ligure $A$ shows a prosetyger of one of :wo bemi-rylindriral strurturs that will house the mudules. The

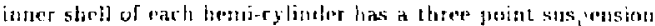
system whirh atiarhes to the leran prine. The slots in ther end-

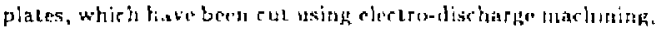
support the mudules al earla ind. A spristg fixture that is atlar hed on pach end of the moulale is compressed when juserled? into the slots. 'lests show that the resulting force keness the radial and to boation of modules stable to witl in $2 \mu m$ while ailowing for a small $z$ tustiun that prevents the bowing of the silicon detectors fom the differential thermal axpansion of the inaterials of the SSYD. The support structures wilt he fistiricated out of aluminium except for the shells in the demertor fogion which will be beryllingu (250 peth thirkness)

The slot lorations in the probetgye endplites hase befn

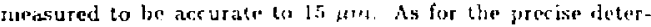
Iniration of the module lorations, a indicod using a collinated $X$-ray beam is being contsidered. One wotuld move the hemi-

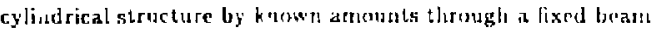

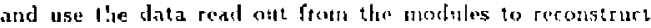
their relative orientations. The $\mathrm{X}$-rass will penetrate the naterials of the module's atd hensing su the aligmment cath be done whell the SSVD assembly is complete. "[ests wi]l begin shortly using a high power ronvertional $X-e a y$ tube to cherk whether this bechuigue will give the retguired accuracy.

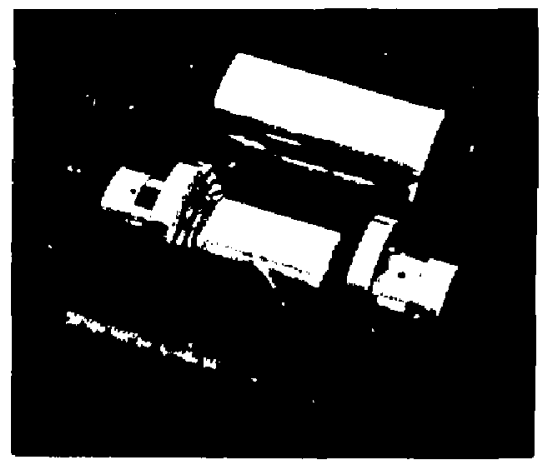

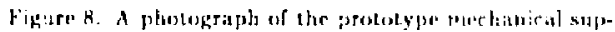

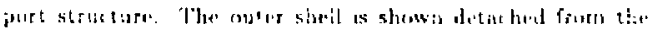

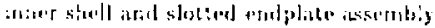

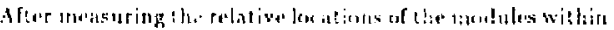

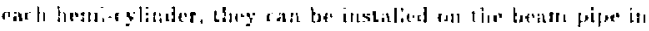

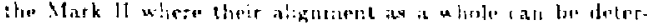

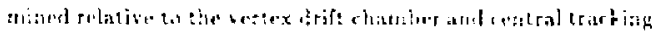

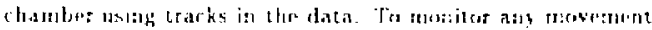

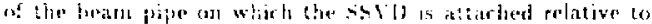

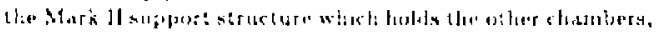

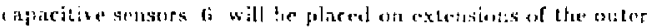

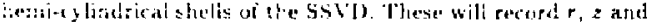

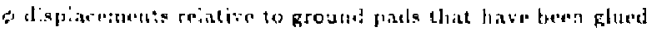

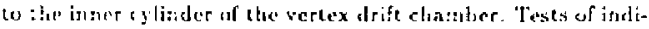

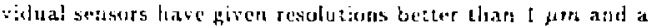

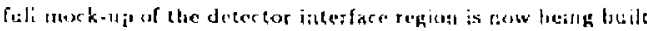

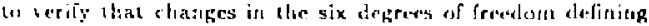
the relatice orsentation of bo beter tors can be unfolded with

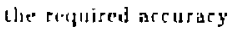

\section{Simmuary and Oatlocsk}

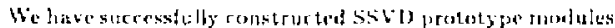

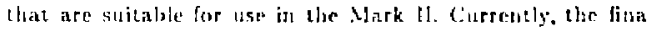
sat we flexible cabjes, hybrids and detectors are britg loult in preparation for full assembly to begin rarly hext bear. One uncertiabuly ihat reuatus is whether the new fabrication of the

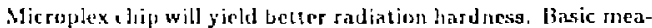
surements of the stability of the wechaniral support atructure have been made and atiention is now tursing more toward the aligturuent question. If things go arcording to plan, we should have the detertor ready for iastallation is the Mark 11 by next sumutuer.

\section{Roforruces}

1. Version 2 of the Mfieruplex chip is deseribed in Q A Anzivines et al, Nucl. Instrum. \& Methods A 243, (1V80) 153 .

2 The detectors describel in the text were fabricated by

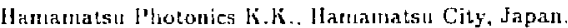

3 C. Adolphisen ef al, Yuet Instrunt a dethods A 253, (1987) 4.1

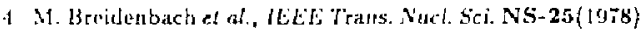
706 .

5' For details on Llee offect of radiatican wa M ic sopicx 2 and 3 , sec the report by $P$. Dauncey ed al., from this conference.

6. The sensors are manufactured by Cipacilec, Iree af hyer, Marsachusetts. 


\section{DISCLAIMER}

This report was prepared as an account of work sponsored by an agency of the United States Government. Neither the United States Government nor any agency thereol, nor any of their employees, makes any warranty, express or implied, or assumes any legal liability or responsibility for the eccuracy, completeness, of usefulness of any information, apparatus, product, or process disclosed, or represents that its use would not infringe privately owned rights. Reference herein to any specific commetcial proxtuct, process, or service by trade name, trademark, manufacturer, or otherwise does not necessarily canstiture or imply its endorsement, recommendation, of lavoring by the United States Government or any agency thereof. The views and opinions of authors expressed herein do nol necessarily state or reflect those of the United States Government or any agency thereaf. 